\title{
DATING OF IRON AGE AGRICULTURE IN THE NEGEV HIGHLANDS: A RESPONSE TO SHAHACK-GROSS AND FINKELSTEIN
}

\author{
Hendrik J Bruins ${ }^{1 *} \cdot$ Johannes van der Plicht $^{2,3}$ \\ ${ }^{1}$ Ben-Gurion University of the Negev, Jacob Blaustein Institutes for Desert Research, Bona Terra Department
'Man in the Desert', Sede Boker Campus 84990, Israel.
${ }^{2}$ University of Groningen, Centre for Isotope Research, Groningen, The Netherlands.
${ }^{3}$ University of Leiden, Faculty of Archaeology, Leiden, The Netherlands.
}

ABSTRACT. In this response to the reply by Shahack-Gross and Finkelstein (2017), we present additional data of our research at Horvat Haluqim. This includes phytolith percentages and multicellular phytolith stomata in a thin section of a layer in Terraced Field 12, dated by radiocarbon $\left({ }^{14} \mathrm{C}\right)$ to the Late Bronze-Early Iron Age. We also show thin-section evidence of aggrading sediment laminations in this terraced field. A new ${ }^{14} \mathrm{C}$ date is given of the Early Islamic Period in Terraced Field 7, as differences in terrace wall architecture are highlighted. We revisit the interpretation by Shahack-Gross and Finkelstein in relation to herd management. Our ${ }^{14} \mathrm{C}$ dates attest that terrace agriculture based on runoff/floodwater irrigation occurred in the Negev Highlands during several periods, including the Iron Age.

KEYWORDS: AMS dating, microarchaeology, Negev Desert, runoff/floodwater, terrace agriculture.

\section{INTRODUCTION}

We acknowledge the expertise of Shahack-Gross concerning the study of phytoliths, dung, and related microarchaeological investigations. Nevertheless, we strongly disagree with the conclusion by Shahack-Gross and Finkelstein that there was no agriculture in the central Negev Highlands during the Iron Age, as stated by them repeatedly (Shahack-Gross and Finkelstein 2008, 2015, 2017; Shahack-Gross et al. 2014).

We have presented in our rejoinder (Bruins and van der Plicht 2017a) various reasons why we disagree with them. We also reported new evidence for Iron-Age agriculture in the region with a series of newly published radiocarbon $\left({ }^{14} \mathrm{C}\right)$ dates from within the stratigraphy of an ancient agricultural terraced wadi field at Horvat Haluqim. However, in their reply, Shahack-Gross and Finkelstein (2017) bring up new arguments against the validity of this consistent series of ${ }^{14} \mathrm{C}$ dates, as well as other contentions. Needless to say that we feel obliged to write a response in order to present our opinion on these issues. We also include new unpublished data from our research.

\section{REVISITING THE INTERPRETATION BY SHAHACK-GROSS AND FINKELSTEIN}

The authors restate in their reply the rationale of their interpretation: "the low concentrations of phytoliths in dung deposits and dung pellets in the two Iron Age sites that we have investigated, indicate that livestock grazed on the natural, phytolith-poor vegetation typical of the Negev Highlands. From this, and based on comparison to phytolith assemblages in the better-watered areas to the north, we concluded that there is no evidence for agricultural practice in the Negev Highlands during the Iron Age" (Shahack-Gross and Finkelstein 2017). It is clear that their evidence is indirect, as they did not investigate agricultural installations, but rooms and courtyards. Bruins studied traditional grazing management and drought-coping strategies of arid-zone pastoralists in the Negev and in Kenya (Bruins et al. 2003). Several animal husbandry patterns were distinguished among the Bedouin in the northern Negev, as investigated in detail by Ben-David (1982). Keeping sheep and goats implies that they require food 365 days per year. Some Bedouin families utilized a system of grazing only on natural vegetation during the entire year. Other families in the northern Negev, who had agricultural fields with wheat or barley,

\footnotetext{
*Corresponding author. Email: hjbruins@bgu.ac.il.
} 
also needed to feed their herds on grazing of natural vegetation during most months of the year! Only after the harvest of barley and wheat, usually around May, was it possible to feed the herd by grazing the remaining stubble at the agricultural fields for some time during the summer months, depending on the size of these fields and the quantity of stubble.

The central Negev Highlands encompass an area of about $2000 \mathrm{~km}^{2}$, in which the collective area of ancient terraced fields in wadis totals ca. $40 \mathrm{~km}^{2}$, as mapped by Kedar (1967). Thus the total area of ancient terraced fields amounts to only $2 \%$ of the region. Considering the architecture of stone terrace walls (Bruins 1990), a topic expanded below, it is clear that many fields were terraced for the first time only in the Roman-Byzantine and Early Islamic Periods. Therefore, the total agricultural area in the Negev Highlands during the Iron Age must have been smaller than the 4000 hectares mapped by Kedar (1967). The ancient inhabitants of the region during the Iron Age had only limited agricultural resources for grazing, such as stubble. Their domesticated herds were even more dependent on natural vegetation as compared to the people who lived in the region during the Byzantine period, or the Bedouin in recent times in the wetter northern Negev. Therefore, we agree that during the Iron Age "livestock grazed on the natural, phytolith-poor vegetation typical of the Negev Highlands" (Shahack-Gross and Finkelstein 2017). However, this does not mean there was no agriculture in the region during the Iron Age. It is here, in the realm of interpretation and extrapolation that we strongly disagree with Shahack-Gross and Finkelstein.

\section{DRY FARMING IN THE NEGEV HIGHLANDS?}

Agriculture is a rather complex system with many aspects, particularly in a desert environment. Shahack-Gross and Finkelstein (2017) use in their abstract the term "timing of dry farming in the Negev Highlands." Dry farming means it is based only on direct rainfall without the use of irrigation water. Such a farming system is not feasible in the Negev Highlands where the average annual rainfall is only about $75-100 \mathrm{~mm}$ per year. Though climatic fluctuations occurred during the past millennia, it has been shown by Bruins (2012) that even very wet annual fluctuations, such as the year 1991-92, hardly penetrate into the central Negev Highlands. On the other hand, drought years often affect the entire country of Israel. Therefore, it seems that dry farming was not feasible in the Negev Highlands in the past. The widespread distribution of stone terrace walls in dry valleys (wadis) show that agriculture in this region was only viable with the addition of irrigation water, in the form of runoff and floodwater, derived from adjacent hillslope catchments, and captured by the terrace walls of the agricultural fields.

\section{EFFECT OF RUNOFF FROM HILLY SLOPE CATCHMENTS ON PHYTOLITH COMPOSITION IN ANCIENT AGRICULTURAL TERRACED WADI FIELDS}

Concerning the five samples from ancient agricultural terraced fields submitted to Albert in 2003 for phytolith and spherulite analysis, four came from Horvat Haluqim and one from another site. Only one sample of Horvat Haluqim (Area 1, 50-57 cm depth) was derived from a buried A-horizon in the time range of Late Bronze to Iron Age I, according to ${ }^{14} \mathrm{C}$ dating (Bruins and van der Plicht 2017a: Table 2). Albert (University of Barcelona) is a renowned expert in the field of phytolith studies and microarchaeology. Her results of the above sample were as follows (numbers estimated from a figure in her internal report, as exact data were not provided): Total grass $47 \%$, Total dicot leaves $5 \%$, Total dicot wood/bark $23 \%$, Others $2 \%$, Weathered morphotypes $22 \%$. For comparison, the sample from the deeper layer (Area 1, $143-150 \mathrm{~cm}$ ) in the same terraced field section (Bruins and van der Plicht 2017a: Table 2), which predates any agricultural activities at the site, has the following phytolith morphologies 
(numbers estimated, as mentioned above): total grass $8 \%$, total dicot leaves 3\%, total dicot wood/bark $69 \%$, others $3 \%$, weathered morphotypes $14 \%$.

Albert (2003) concluded in her internal report that the phytolith results did not give any evidence of agricultural activities. She also concluded that "more experiments need to be carried out in order to better quantify the differences observed." Indeed more studies have to be made, because the phytolith composition of ancient agricultural fields in desert regions, characterized by runoff flows from surrounding hilly catchments, cannot be compared with agricultural fields in dry farming systems, situated in semi-arid landscapes with a stable geomorphic surface, receiving only rainfall.

The seasonal incoming runoff flows with sediment in desert runoff/floodwater systems (Bruins et al. 1986) are likely to contain phytoliths from the dominant woody desert shrub vegetation growing on the hillslope catchments. The Bushy Bean Caper plant, Zygophyllum dumosum, is most common in the Horvat Haluqim area, having a height of about $30-50 \mathrm{~cm}$, while being diffusely branched. Such vegetation is likely to add dicot wood/bark phytoliths, transported by runoff flows, to the terraced agricultural fields. Therefore, the above phytolith composition result by Albert (2003) for the buried A-horizon $(50-57 \mathrm{~cm})$ is not a simple record of the vegetation that was growing on the agricultural field, but is bound to include also shrub phytoliths (dicot wood/ bark) from the hillslope catchment. The above results by Albert clearly show that the amount of grass phytoliths, which belong to the festucoid subfamily, the most common group of grasses in the Mediterranean area that include species such as wheat and barley, is largest (ca. 47\%) in the Late Bronze to Early Iron Age layer (Area 1, 50-57 cm). The deeper pre-agricultural layer (Area $1,143-150 \mathrm{~cm})$ in the same section contains only ca. $8 \%$ of grass phytoliths.

The few samples submitted to Albert in 2003 were investigated using standard laboratory procedures (Albert et al. 1999). She reported the absence of multicellular structures of grass phytoliths in these samples. However, subsequent micromorphology studies of large-size thin sections made from undisturbed soil samples of the Late Bronze and Iron Age agricultural layers at Horvat Haluqim, conducted together with Portillo at the University of Barcelona, did show the regular occurrence of multicellular structures of grasses, as shown for example in Figure 1. The simultaneous use of thin section micromorphology with conventional phytolith analysis is advocated by Shillito (2011).

\section{IRON AGE AND LATE BRONZE AGE RADIOCARBON DATES FROM TERRACED FIELD 12 IN THE EASTERN WADI OF HORVAT HALUQIM}

In their reply, Shahack-Gross and Finkelstein (2017) question the validity of our radiocarbon dates in relation to sedimentology (Shahack-Gross and Finkelstein 2017): "This brings us to the question, what is the most suitable methodology for dating terrace construction and use - radiocarbon or OSL? Bruins and van der Plicht support the former, arguing that sediment accumulation behind terraces captures datable materials that define terrace use-life. This might have been acceptable had the authors showed that they date a laminated, rather than homogenous fill [which they fail to show even via micromorphology (Bruins and van der Plicht 2017a)]. Therefore, the seeming development in age along the dated profile of sediments presented by Bruins and van der Plicht (2017a: Table 1), cannot be evaluated from a sedimentological point of view."

This can easily be refuted. Hereby we present the requested micromorphology of lamination caused by water flow, sedimentation and soil surface crust formation, which is clearly visible in Terraced Field 12, as shown in the photograph of the large-size thin section (Figure 2). 


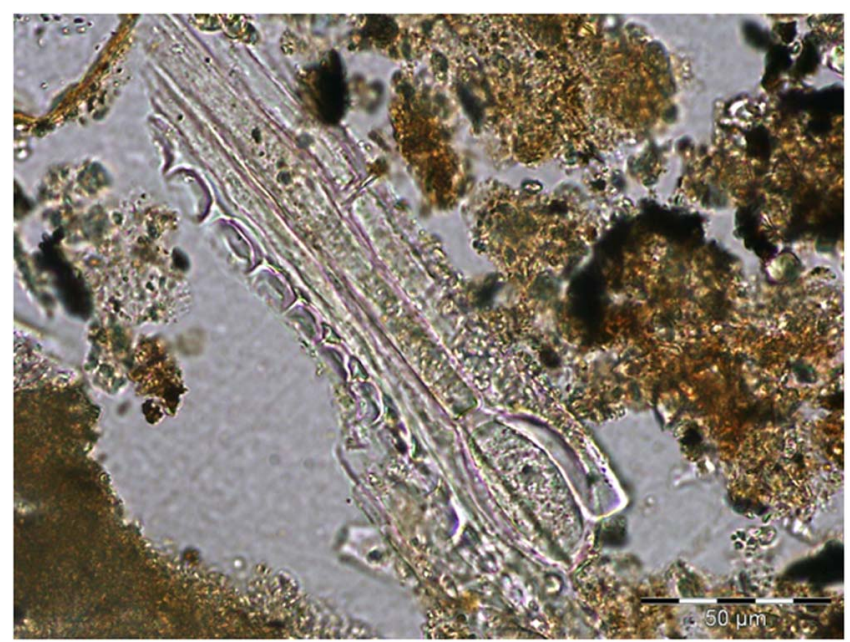

Figure 1 Multicellular phytolith stomata of grasses (PPL view) in undisturbed soil sample from Horvat Haluqim, Eastern Wadi, Terraced Field 12 , Area $5,47-55 \mathrm{~cm}$. This level is dated by ${ }^{14} \mathrm{C}$ to the range of Late Bronze-Early Iron Age (Bruins and van der Plicht 2017a; Bruins et al. in press). The photograph was taken during joint microscope sessions by Bruins and Portillo in 2012 at the University of Barcelona (Department of Prehistory, Ancient History and Archaeology).

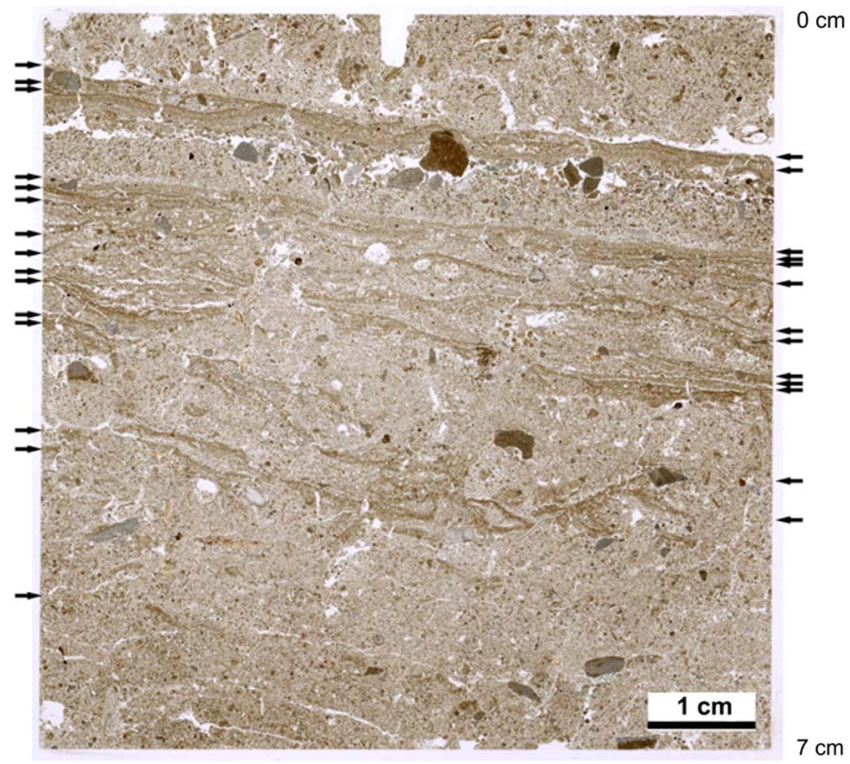

Figure 2 Horvat Haluqim, Eastern Wadi, Terraced Field 12, Area 3, Layer I-AC, thin section $02113,0-7 \mathrm{~cm}$ depth. Visible sedimentation laminae are indicated by arrows along both sides of the thin section.

This vertical thin section (02113) is from a depth of $0-7 \mathrm{~cm}$ within the upper layer I-AC in Area 3. The micromorphology shows a sequence of about 7 buried laminated surface crusts, parallel to each other in the upper $5 \mathrm{~cm}$, characterized by graded bedding (Figure 2). The upper two laminated crusts are continuous, but show cracks, apparently due to drying and volume 
change, as swelling clay minerals dominate in the alluvial loess. Some fragments of land snail shells, visible on the microscale along the laminated crusts, also moved with the runoff water. The laminae look more and more diffuse and degraded in a downward direction, apparently due to biological activity, i.e. bioturbation. Hardly any crust remnants remain in the lower $2 \mathrm{~cm}$ of the thin section (5-7 cm depth).

The presence of parallel laminated surface crusts is clear evidence that flows of runoff water and alluvial aggradation on Terraced Field 12 continued until sedimentation reached the uppermost part of Terrace Wall 12. Moreover, the sequence of buried crusts provides unequivocal confirmation that the field was not cultivated and ploughed during the time represented by the aggrading laminae in the upper part of the thin section. At present most water on Terraced Field 12 flows along a shallow erosional stream bed in the western part of the field in Area 5. It seems that alluvial sedimentation in Area 3 is limited at present, due to its comparatively elevated position on the terraced field. Moreover, sediment aggradation has reached the uppermost level of the stone terrace wall, so that runoff water will continue to flow unimpeded downstream to the next terraced field.

It is clear from the above evidence that sedimentological processes did play a role in the gradual aggradation of terraced fields at Horvat Haluqim. Therefore, the above contention by ShahackGross and Finkelstein (2017) against the validity of our ${ }^{14} \mathrm{C}$ dates can be rejected. Needless to say that it would be unusual, if the ${ }^{14} \mathrm{C}$ dates, which all appear in a systematic order in relation to their respective stratigraphic position, would not be related to a gradual aggradation of the surface of the terraced field, on which people carried out their agricultural activities and left their imprints of organic remains, related by us to manuring from kitchen refuse sources and dung. However, as sedimentological laminae become buried by new sediment layers, ongoing biological activity by soil fauna, i.e. bioturbation, will gradually obliterate the laminae. Moreover, human agricultural activities on the soil surface of the terraced fields can also obliterate such sediment layers, even within a year of sedimentation, as elaborated below.

Bruins and Haiman have excavated two silos next to Terraced Field 12 (not yet published). We uncovered a flint sickle blade with gloss in one of these silos. Such a gloss is generally understood to be derived from cereal crops during the cutting of the stems in the harvesting process. The sickle blade was dated by Steve Rosen (personal communication) to the Bronze or Iron Age, on the basis of its typological features. The archaeological findings indicate that cereals were grown in some of the terraced fields in the Eastern Wadi of Horvat Haluqim. The comparatively high percentage of grass phytoliths (ca. 47\%) in the Late Bronze-Iron Age layer, as shown by ${ }^{14} \mathrm{C}$ dates, in comparison to the deeper and older pre-agricultural terrace layer (ca. 8\%), supports the archaeological evidence. The sowing of cereal seeds requires mechanical disturbance of the surface soil, either by plowing, harrowing or a digging stick, in order to cover the seeds with soil. This will obviously destroy the fine laminations of sedimentary layers aggrading on the field from seasonal runoff flows.

\section{Terrace Wall Architecture}

Shahack-Gross and Finkelstein (2017) repeatedly advocate their view that stone terrace wall construction in the Negev Highlands did not predate the Roman period. All experts agree that the Byzantine Period witnessed the culmination of agricultural activity and terrace wall construction in the region, which is also mentioned by Bruins (2012) in a comprehensive study of ancient agriculture in the region. The architecture of terrace walls in the Roman-Byzantine and Early Islamic periods display a sophisticated level of construction with very neat and ordered 
rows of stones. A detailed drawing of such terrace wall construction can be found in an article by Bruins (1990) concerning the Byzantine to Early Islamic site of Nahal Mitnan in the western Negev Highlands, near the border with Egypt.

However, the prominent Terrace Wall 12 in the Eastern Wadi of Horvat Haluqim shows a totally different, rather chaotic architecture, reflecting its more ancient and complex origin well before the Roman period, as shown by the radiocarbon dates of the Late Bronze and Iron Age (Bruins and van der Plicht 2017a). Sometimes ancient terrace walls may become buried by sedimentation, disappearing from view and after gaps in habitation new settlers may build new terrace walls on aggraded soil surfaces. For example, Terrace Wall 7 in the Eastern Wadi of Horvat Haluqim is much lower in height than Terrace Wall 12 and shows a totally different architecture. It is characterized by double wall architecture with orderly rows of stones, similar to the terrace wall at Nahal Mitnan (Bruins 1990), albeit of smaller size. Indeed the radiocarbon date we have of Terrace Wall 7 (Eastern Wadi, Horvat Haluqim) fits the Early Islamic Period. The material dated is a small spot of charred organic material (COM), found during excavations at a depth of $11-22 \mathrm{~cm}$ in the terraced field close to the stone terrace wall: GrA-22456, $1105 \pm 40 \mathrm{BP}$. The calibrated date range is $894-985(1 \sigma)$ cal AD or $778-1020(2 \sigma)$ cal AD. We used the IntCal13 calibration curve (Reimer et al. 2013) and the OxCal v 4.2 program (Bronk Ramsey 2001, 2009).

\section{CONCLUSION}

We have by now more than a hundred ${ }^{14} \mathrm{C}$ dates of Horvat Haluqim. These will be published in a topical way in relation to the various terrace and building structures investigated at this rural desert site. Shahack-Gross and Finkelstein (2017) point out that our publications concerning the age of ancient agriculture at Horvat Haluqim have focused so far only on one terraced field. That is true. But it is an ancient agricultural terraced field, not an indirect association from rooms and courtyards, as published by them.

Our ${ }^{14} \mathrm{C}$ results of this terraced field (Bruins and van der Plicht 2017a) are consistent with the stratigraphy, showing that agriculture based on runoff/floodwater capture already existed in the Late Bronze and Early Iron Age. However, human habitation and use of the terraced fields was not continuous. There were intervals of abandonment, during which sometimes erosion occurred. Yet the terraced fields remained, terrace walls were repaired by new settlers, or rebuilt on higher (aggraded) soil levels, as is the case for Terrace Wall 7, in the Eastern Wadi, during the Early Islamic Period. If ${ }^{14} \mathrm{C}$ dating results are acceptable for the latter period, they should also be accepted for the Late Bronze and Early Iron Age, and even for the Late Neolithic, for which we also have a series of ${ }^{14} \mathrm{C}$ dates.

\section{ADDENDUM}

We also have now OSL dates for Horvat Haluqim (Naomi Porat, personal communication, 2017). The results in a terraced field in the eastern wadi support our radiocarbon dates concerning terrace layers that accumulated in the Late Bronze Age. However, the OSL dates of Horvat Haluqim obviously cannot be presented in this reply, but will be published in another article, in which all participating researchers are involved.

\section{REFERENCES}

Albert RM. 2003. Phytolith and spherulite analyses from the site of Horvat Haluqim (Negev, Israel). Internal report. University of Barcelona.
Albert RM, Tsatskin A, Ronen A, Lavi O, Estroff L, Lev-Yadun S, Weiner S. 1999. Mode of occupation of Tabun Cave, Mt Carmel, Israel, during the 
Mousterian Period: a study of the sediments and phytoliths. Journal of Archaeological Science 26:1249-60.

Ben-David J. 1982. Stages in the sedentarization of the Negev Bedouin, a transition from former seminomadic to settled population [unpublished $\mathrm{PhD}$ thesis]. Jerusalem: The Hebrew University of Jerusalem.

Bronk Ramsey C. 2001. Development of the radiocarbon calibration program OxCal. Radiocarbon 43(2A):355-63.

Bronk Ramsey C. 2009. Bayesian analysis of radiocarbon dates. Radiocarbon 51(1):337-60.

Bruins HJ. 1990. Ancient agricultural terraces at Nahal Mitnan. Atiqot 10:127-8 (Hebrew), $22 *-28 *$ (English).

Bruins HJ. 2012. Ancient desert agriculture in the Negev and climate-zone boundary changes during average, wet and drought years. Journal of Arid Environments 86:28-42.

Bruins HJ, Evenari M, Nessler U. 1986. Rainwater harvesting agriculture for food production in arid zones: the challenge of the African famine. Applied Geography 6:13-32.

Bruins HJ, Akong'a JJ, Rutten MMEM, Kressel GM. 2003. Drought Planning and Rainwater Harvesting for Arid-Zone Pastoralists: the Turkana and Maasai (Kenya) and the Negev Bedouin (Israel). NIRP Research for Policy Series 17. Amsterdam: KIT Publishers.

Bruins HJ, van der Plicht J. 2017a. Iron Age agriculturea critical rejoinder to "Settlement oscillations in the Negev Highlands revisited: the impact of microarchaeological methods". Radiocarbon 59(1): 1-16. DOI: 10.1017/RDC.2016.95.

Bruins HJ, van der Plicht J. 2017b. Dating of Iron Age agriculture in the Negev Highlands: a response to Shahack-Gross and Finkelstein. Radiocarbon 59(4): 1233-9.

Bruins HJ, Segal I, van der Plicht J. In press. Bronze chisel at Horvat Haluqim (central Negev highlands) in a sequence of radiocarbon dated Late
Bronze to Iron Age I living floors. In: Ben-Yosef E, Goren Y, editors. Mining for Copper: Essays in Honor of Professor Beno Rothenberg. Tel Aviv: Occasional Publication, Institute of Archaeology of Tel Aviv University.

Kedar Y. 1967. The Ancient Agriculture in the Negev Mountains. Jerusalem: Bialik Institute.

Reimer PJ, Bard E, Bayliss A, Beck JW, Blackwell PG, Bronk Ramsey C, Buck CE, Cheng $\mathrm{H}$, Edwards RL, Friedrich M, Grootes PM, Guilderson TP, Haflidason H, Hajdas I, Hatté C, Heaton TJ, Hoffmann DL, Hogg AG, Hughen KA, Kaiser KF, Kromer B, Manning SW, Niu M, Reimer RW, Richards DA, Scott EM, Southon JR, Staff RA, Turney CSM, van der Plicht J. 2013. IntCal13 and Marine13 radiocarbon age calibration curves 0-50,000 years cal BP. Radiocarbon 55(4):1869-87.

Shahack-Gross R, Boaretto E, Cabanes D, Katz O, Finkelstein I. 2014. Subsistence economy in the Negev Highlands: the Iron Age and the Byzantine/ Early Islamic period. Levant 46(1):98-117.

Shahack-Gross R, Finkelstein I. 2008. Subsistence practices in an arid environment: a geoarchaeological investigation in an Iron Age site, the Negev Highlands, Israel. Journal of Archaeological Science 35(4):965-82.

Shahack-Gross R, Finkelstein I. 2015. Settlement oscillations in the Negev Highlands revisited: the impact of microarchaeological methods. Radiocarbon 57(2):253-64.

Shahack-Gross R, Finkelstein I. 2017. Iron Age agriculture in the Negev Highlands? Methodological and factual comments on Bruins and van der Plicht 2017a (Radiocarbon Vol. 59, Nr. 1). Radiocarbon 59(4), 1227-31.

Shillito LM. 2011. Simultaneous thin section and phytolith observations of finely stratified deposits from Neolithic catalhoyuk, Turkey: implications for paleoeconomy and Early Holocene paleoenvironment. Journal of Quaternary Science 26(6):576-88 